\title{
Tumor Suppressor Schwannomin/Merlin Is Critical for the Organization of Schwann Cell Contacts in Peripheral Nerves
}

\author{
Natalia Denisenko, ${ }^{1,2,3 *}$ Carmen Cifuentes-Diaz, ${ }^{1,2,3 *}$ Theano Irinopoulou, ${ }^{1,2,3}$ Michèle Carnaud, ${ }^{1,2,3}$ Evelyne Benoit, ${ }^{4}$ \\ Michiko Niwa-Kawakita, ${ }^{5,6}$ Fabrice Chareyre, ${ }^{5,6}$ Marco Giovannini, ${ }^{5,6}$ Jean-Antoine Girault, ${ }^{1,2,3}$ and \\ Laurence Goutebroze ${ }^{1,2,3}$ \\ ${ }^{1}$ Inserm, Unité Mixte de Recherche en Santé 839, Paris, 75005, France, ${ }^{2}$ Université Pierre et Marie Curie-Paris 6, Paris, 75005, France, ${ }^{3}$ Institut du Fer à \\ Moulin, Paris, 75005, France, ${ }^{4}$ Centre National de la Recherche Scientifique, Institut de Neurobiologie Alfred Fessard, Laboratoire de Neurobiologie \\ Cellulaire et Moléculaire, Unité Propre de Recherche 9040, Gif sur Yvette, 91198, France, ${ }^{5}$ Inserm, Unité 674, Paris, 75010, France, and 6Université Paris \\ 7-Denis Diderot, Institut Universitaire d'Hématologie, Paris, 75010, France
}

Schwannomin/merlin is the product of a tumor suppressor gene mutated in neurofibromatosis type 2 (NF2). Although the consequences of NF2 mutations on Schwann cell proliferation are well established, the physiological role of schwannomin in differentiated cells is not known. To unravel this role, we studied peripheral nerves in mice overexpressing in Schwann cells schwannomin with a deletion occurring in NF2 patients ( $\mathrm{P0}-\mathrm{SCH}-\Delta 39-121)$ or a C-terminal deletion. The myelin sheath and nodes of Ranvier were essentially preserved in both lines. In contrast, the ultrastructural and molecular organization of contacts between Schwann cells and axons in paranodal and juxtaparanodal regions were altered, with irregular juxtaposition of normal and abnormal areas of contact. Similar but more severe alterations were observed in mice with conditional deletion of the Nf2 gene in Schwann cells. The number of SchmidtLanterman incisures, which are cytoplasmic channels interrupting the compact myelin and characterized by distinct autotypic contacts, was increased in the three mutant lines. $\mathrm{P} 0-\mathrm{SCH}-\Delta 39-121$ and conditionally deleted mice displayed exuberant wrapping of nonmyelinated fibers and short internodes, an abnormality possibly related to altered control of Schwann cell proliferation. In support of this hypothesis, Schwann cell number was increased along fibers before myelination in $\mathrm{P} 0-\mathrm{SCH}-\Delta 39-121$ mice but not in those with C-terminal deletion. Schwann cell numbers were also more numerous in mice with conditional deletion. Thus, schwannomin plays an important role in the control of Schwann cell number and is necessary for the correct organization and regulation of axoglial heterotypic and glio-glial autotypic contacts.

Key words: neurofibromatosis type 2; nodes of Ranvier; paranodes; juxtaparanodes; Schmidt-Lanterman incisures; internodes

\section{Introduction}

Neurofibromatosis type 2 (NF2) is a dominant autosomic disease characterized by the occurrence of multiple schwannomas, as well as ependymomas and meningiomas. The $N f 2$ tumor suppressor gene codes for a protein closely related to ezrin, radixin, and moesin (ERM) termed schwannomin (Rouleau et al., 1993) or merlin (Trofatter et al., 1993). Cell type-specific mutations of schwannomin or its absence lead to tumor formation in various mouse tissues (McClatchey et al., 1998; Giovannini et al., 1999, 2000; Kalamarides et al., 2002). Schwannomin is thought to play

Received June 2, 2008; revised Aug. 1, 2008; accepted Aug. 10, 2008.

This work was supported in part by grants of the National Multiple Sclerosis Society, Association pour la Recherche sur la Sclerose en Plaque, Association Française contre les Myopathies, Action Concertée Incitative Développement et Physiologie, Association pour la Recherche sur le Cancer, Foundation Schlumberger pour l'enseignement et la Recherche, and Agence Nationale de la Recherche-Neuro-05-NEUR-A05158DS. We are indebted to P. Ezan, A. Boisquillon, C. Fayet, P. Bozin, and E. Valjent for their help with some experiments.

${ }^{*} N$.D. and C.C.-D. contributed equally to this work.

Correspondence should be addressed to Jean-Antoine Girault, Inserm, Unité Mixte de Recherche en Santé 839, Institut du Fer à Moulin, 17 rue du Fer à Moulin, Paris, 75005, France. E-mail: jean-antoine.girault@inserm.fr.

M. Giovannini's present address: The Center for Neural Tumor Research, House Ear Institute, Keck School of Medicine, University of Southern California, Los Angeles, CA 90057.

DOI:10.1523/JNEUROSCI.2537-08.2008

Copyright $\odot 2008$ Society for Neuroscience 0270-6474/08/2810472-10\$15.00/0 a critical role at the plasma membrane, controlling cell-cell interactions and signaling pathways triggered by cell contacts (McClatchey and Giovannini, 2005; Okada et al., 2007). It stabilizes adherens junctions (Lallemand et al., 2003) and interacts with the cytoskeleton, cytoskeleton-associated proteins, many transmembrane and adaptor-scaffold proteins, and a variety of signaling proteins (Okada et al., 2007). However, besides its importance as a tumor suppressor, the physiological role of schwannomin is still poorly understood, and its function in differentiated Schwann cells is not known.

During development of peripheral nerves, immature Schwann cells give rise to myelinating nonmyelinating cells (Sherman and Brophy, 2005). Nonmyelinating Schwann cells ensheath small-diameter axons $(<1 \mu \mathrm{m})$, whereas myelination takes place in Schwann cells wrapped around large-diameter axons. In myelinated fibers, the voltage-gated $\mathrm{Na}^{+}$channels are concentrated at nodes of Ranvier between adjacent Schwann cells, allowing the rapid saltatory conduction of action potentials. Myelination requires a complex series of interactions between myelinating Schwann cells and axons, which results in highly differentiated domains along the axon (Arroyo and Scherer, 2000). These domains are centered by nodes of Ranvier, which 
are flanked on either sides by paranodal junctions and juxtaparanodal regions. Paranodal junctions separate $\mathrm{Na}^{+}$channels at the node and shaker-type $\mathrm{K}^{+}$channels at the juxtaparanode and function as barriers to restrict the lateral diffusion of axonal membrane proteins and extracellular molecules between the node and the internodal space (Poliak and Peles, 2003). Although a number of molecules involved in axoglial contacts have been identified during the past few years (Girault and Peles, 2002; Poliak and Peles, 2003; Salzer, 2003), their organization remains poorly understood. Because of its proposed role in cell contacts, schwannomin is an interesting candidate for playing a role in the organization of axoglial contacts. Schwannomin-like immunoreactivity has been reported in paranodal regions and SchmidtLanterman incisures (SLIs) (Scherer and Gutmann, 1996), which are cytoplasmic channels interrupting the compact myelin. In neurons, schwannomin can associate with the cytoplasmic tail of the paranodal protein paranodin/Caspr (Denisenko-Nehrbass et al., 2003), whereas in Schwann cells, it is localized to the plasma membrane through a paxillin-mediated interaction with $\beta 1$ integrin (Obremski et al., 1998; Fernandez-Valle et al., 2002).

To address the function of schwannomin in vivo, we used mouse lines with targeted overexpression of mutated schwannomin in Schwann cells or bearing a conditional deletion of the $N f 2$ gene in Schwann cells. Our results indicate an important role of schwannomin in the organization of Schwann cell contacts and provide new clues about its function.

\section{Materials and Methods}

Mice. Transgenic mice overexpressing mutated forms of human schwannomin under the control of the $\mathrm{P} 0$ promoter were obtained as described previously (Giovannini et al., 1999). In P0-SCH- $-\Delta 39-121$ mice (line 27), exons 2 and 3 , which code for amino acid residues 39-121 within the FERM domain of isoform 1, have been deleted (supplemental Fig. 1, available at www.jneurosci.org as supplemental material). This deletion corresponds to a known mutation in Nf2 patients. In $\mathrm{P} 0-\mathrm{SCH}-\Delta$ Cter mice (line 3), the $\mathrm{C}$-terminal residues beyond amino acid 314 were deleted (supplemental Fig. 1, available at www.jneurosci.org as supplemental material). Conditional deletion of schwannomin in Schwann cells was obtained as described previously (Giovannini et al., 2000) by crossing two lines of transgenic mice: one in which exon 2 of $N f 2$ was flanked by LoxP sequences (supplemental Fig. 1, available at www.jneurosci.org as supplemental material), and the other expressing the Cre recombinase under the control of the $\mathrm{P} 0$ promoter $\left(\mathrm{PO}-\mathrm{Cre}^{B}\right)$. The animals used for experiments $\left(\mathrm{P} 0 \mathrm{CreB} ; \mathrm{Nf2^{ \text {flox } 2 / f l o x 2 }}\right.$ ) had two floxed $\mathrm{N} f 2$ alleles and were hemizygous for $\mathrm{P} 0-\mathrm{Cre}^{\mathrm{B}}$. These animals are referred as P0Cre; $\mathrm{Nf} 2^{\text {flox2 } / f l o x 2}$ mice.

Electron microscopy and morphometry. Mice were anesthetized with pentobarbital and perfused with $0.9 \% \mathrm{NaCl}$, followed by $4 \%$ paraformaldehyde and $3 \%$ glutaraldehyde in $0.1 \mathrm{~m}$ phosphate buffer (PB). The sciatic and phrenic nerves were removed and placed in fresh fixative overnight at $4^{\circ} \mathrm{C}$, rinsed in $\mathrm{PB}$, postfixed in $2 \%$ OsO4 in $\mathrm{PB}$, dehydrated in an ascending series of ethanol, and embedded in epoxy resin. Semithin sections $(0.5 \mu \mathrm{m})$ were stained with toluidine blue and viewed with a Leica DMRAX light microscope. Morphometric analyses were performed on $0.5 \mu \mathrm{m}$ semithin transversal sections from phrenic nerves of three different mice of each phenotype. G-ratios were calculated as ratios of internal to external perimeters of the myelin sheath, measured automatically after segmentation, in $>100$ fibers per section (Michailov et al., 2004). Ultrastructural studies were performed on transversal sections of the phrenic nerves and on longitudinal sections of the sciatic nerves. Ultrathin sections $(40 \mathrm{~nm}$ ) were cut, stained with Reynold's lead citrate and uranyl acetate, and viewed with a Philips CM-120 TEM electron microscope. Ten Ranvier nodes, from at least two different 12-month-old mice of each phenotype, were observed, and three paranodal regions were selected from 3- and 6-month-old mice. The size of 10 paranodal loops from 10 heminodes was evaluated by measuring the length of membrane of each loop in contact with the axonal membrane.
Antibodies. Rabbit antibodies against paranodin (L51), Caspr2, and syndecan 4 have been described previously (Menegoz et al., 1997; Denisenko-Nehrbass et al., 2003; Goutebroze et al., 2003). The antineurofascin antibody reacting with NF155 and NF186 was generated by immunizing rabbits with the common intracellular region of the protein (residues 1065-1175; GenBank accession number AY061639) fused to glutathione $S$-transferase. The other antibodies were from the following sources: NF2 rabbit polyclonal antibodies (immunoblotting, A-19 sc331; Santa Cruz Biotechnology); voltage-gated $\mathrm{Na}^{+}$channel $\alpha$ subunit mouse monoclonal antibody (PAN Nav, clone K58/35); polyclonal $\beta$-catenin antibody (Sigma-Aldrich); Kv1.1 $\alpha$ subunit monoclonal antibody (clone K20/78; Millipore); neuronal class III $\beta$-tubulin (TUJ1) and nonphosphorylated neurofilament H (SMI-32) monoclonal antibodies (Covance Research Products); FITC-conjugated sheep anti-rabbit antibodies (Eurobio); cyanine 3 (Cy3)-conjugated goat anti-mouse antibodies (Invitrogen); and IRDye800CW-conjugated donkey anti-mouse and anti-rabbit antibodies (Rockland Immunochemicals).

Immunofluorescence and quantitative studies. Immunostaining of cryostat sections $(10 \mu \mathrm{m})$ or teased fibers of sciatic nerves was performed as described previously (Goutebroze et al., 2003). Images were acquired using a Leica epifluorescence microscope equipped with a CCD camera (Micromax; Roper Scientific), or a Leica SP2 confocal laser scanning microscope. For quantification of internodal length, nodes were identified by voltage-gated $\mathrm{Na}^{+}$channel $\alpha$ subunit and paranodin immunostaining on teased fibers. The diameter of individual fibers was measured after immunolabeling with the Cy3-conjugated goat anti-mouse antibodies that underlined fibers surface. To determine the distance between Schmidt-Lanterman incisures, teased fibers were labeled with an antibody against $\beta$-catenin. Distances between nodes or incisures and axon diameters were measured using MetaMorph software (Molecular Devices). Three-dimensional reconstructions from confocal optical sections $(0.162 \mu \mathrm{m}$ apart $)$ and surface rendering techniques to visualize immunoreactivity as solid objects were done using Imaris 4.0 software (Bitplane).

Lysates preparation and immunoblotting. Sciatic nerves were dissected out and homogenized in a Dounce vessel containing $200 \mu \mathrm{l}$ of a lysis

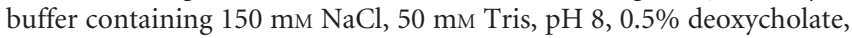
$0.1 \%$ SDS, $1 \%$ NP-40, and Complete proteases inhibitors (Roche Diagnostics). Homogenates were centrifuged $15 \mathrm{~min}$ at $4^{\circ} \mathrm{C}$ at $20,000 \times g$, and protein concentration in the supernatants were determined by the bicincholinic acid method (Sigma-Aldrich). Equal amounts of protein $(20 \mu \mathrm{g})$ were fractionated by SDS-PAGE and transferred to nitrocellulose. Membranes were incubated with primary antibodies followed by appropriate IRDye-conjugated secondary antibodies, and developed and quantified using Odyssey (LI-COR Biosciences).

\section{Results}

\section{In mice overexpressing mutated schwannomin in Schwann cells, myelin sheaths are preserved but nonmyelinated fibers are altered}

To investigate the role of schwannomin in peripheral nerves, we studied two transgenic mouse lines that overexpress in Schwann cells mutated forms of human schwannomin deleted of either amino acid residues 39-121 within the FERM domain (P0$\mathrm{SCH}-\Delta 39-121$ mice) or the C-terminal residues beyond amino acid 314 (P0-SCH- $\Delta$ Cter mice) (Giovannini et al., 1999) (supplemental Fig. 1, available at www.jneurosci.org as supplemental material). In semithin transverse sections of phrenic nerves at low magnification at various ages $(3,6$, and 12 months), the endoneurial space appeared to be increased in $\mathrm{P} 0-\mathrm{SCH}-\Delta 39-121$ mice in which fibers often had an irregular shape (supplemental Fig. 2, available at www.jneurosci.org as supplemental material). However, no dramatic alteration of the number of fibers was found (Table 1). Myelination appeared globally normal, although myelin thickness was marginally increased in $\mathrm{P0}-\mathrm{SCH}-$ $\Delta$ Cter mice, as indicated by a slight reduction of the G-ratio (Table 1). 
Electron microscopy study of transverse sections of phrenic nerve revealed several abnormalities (Fig. 1). In register with increased endoneurial space, collagen pockets between fibers were observed in $\mathrm{P} 0-\mathrm{SCH}-\Delta 39-121$ mice but not in $\mathrm{P} 0-$ $\mathrm{SCH}-\Delta$ Cter or wild-type mice (data not shown). In wild-type mice, groups of unmyelinated fibers were regularly surrounded by a single Schwann cell process (Remak fibers) (Fig. 1A,B), whereas in $\mathrm{P} 0-\mathrm{SCH}-\Delta 39-121$ mice, Schwann cell processes often made several turns around small-caliber axons (Fig. $1 C, D$ ). These abnormalities were not found in $\mathrm{P} 0-\mathrm{SCH}-\Delta$ Cter mice, although some features of aberrant myelination were occasionally present, such as partially undefasciculated bundles of unmyelinated axons surrounded by the same Schwann cell process (Fig. 1E,F). The observation of abnormal wrapping of nonmyelinated fibers indicated that regulation of autotypic cell contacts might be altered in the presence of mutated schwannomin. However, such abnormalities did not affect significantly the formation of myelin sheath.

\section{Overexpression of mutated schwannomin in Schwann cells alters the organization of paranodal and juxtaparanodal proteins}

We examined the role of schwannomin in interactions between Schwann cells and axons, by studying the distribution of proteins enriched at nodes of Ranvier and paranodal junctions, and playing crucial roles in their integrity. In longitudinal sections of sciatic nerves from $\mathrm{P} 0-\mathrm{SCH}-\Delta 39-121$ and $\mathrm{P} 0-\mathrm{SCH}-\Delta$ Cter mice, nodal axonal proteins, $\mathrm{Na}^{+}$channels (Fig. $2 A a-A f$, arrows), and ankyrin G (Kordeli et al., 1990 and data not shown) appeared normally clustered, as in wild-type mice. The distribution of proteins enriched in Schwann cells microvilli that surround the axon at nodes of Ranvier (Melendez-Vasquez et al., 2001; Goutebroze et al., 2003), including syndecan 4 (Fig. $2 \mathrm{Aa}$ $A c$ ), syndecan 3, and ERM proteins (data not shown), was also indistinguishable in mutant and wild-type mice. In contrast, the localization of the paranodal protein paranodin/Caspr was altered in both $\mathrm{P} 0-\mathrm{SCH}-\Delta 39-121$ and $\mathrm{P} 0-\mathrm{SCH}-\Delta$ Cter mice, in sciatic nerve sections (data not shown), and in teased fibers (Fig. $2 B a-B c)$. The labeling was irregular with areas of intense immunoreactivity alternating with regions of low or absent staining. The limits of paranodin distribution, which normally ends rather abruptly at the borders of the paranodal junctions (Fig. $2 \mathrm{Ba}$, arrowheads), with the exception of the labeling along the mesaxon (Fig. $2 \mathrm{Ba}$, arrows), were less regular than in wild-type mice and appeared to protrude into the juxtaparanodal regions (Fig. $2 B b, B c)$. Quantification of the number of paranodes with altered paranodin immunoreactivity revealed that the proportion of abnormal labeling tended to be higher in large fibers (58\% in P0$\mathrm{SCH}-\Delta$ Cter and $76 \%$ in $\mathrm{P} 0-\mathrm{SCH}-\Delta 39-121)$ than in small fibers (36 and 61\%, respectively). We also examined the distribution of neurofascin, a cell adhesion molecule localized in the axon at nodes (NF186 isoform) and in glial loops at paranodes (NF155 isoform) (Tait et al., 2000). Alterations in the localization of paranodal neurofascin in teased fibers of sciatic nerves from P0SCH- $-39-121$ and $\mathrm{P} 0-\mathrm{SCH}-\Delta$ Cter mice were similar to those observed for paranodin (Fig. $2 B d-B f$ ). Three-dimensional reconstructions of paranodin immunolabeling clearly showed its irregular and fragmented organization in mutant mice (Fig. 2C).

We then examined the distribution of Caspr2, a protein nor-
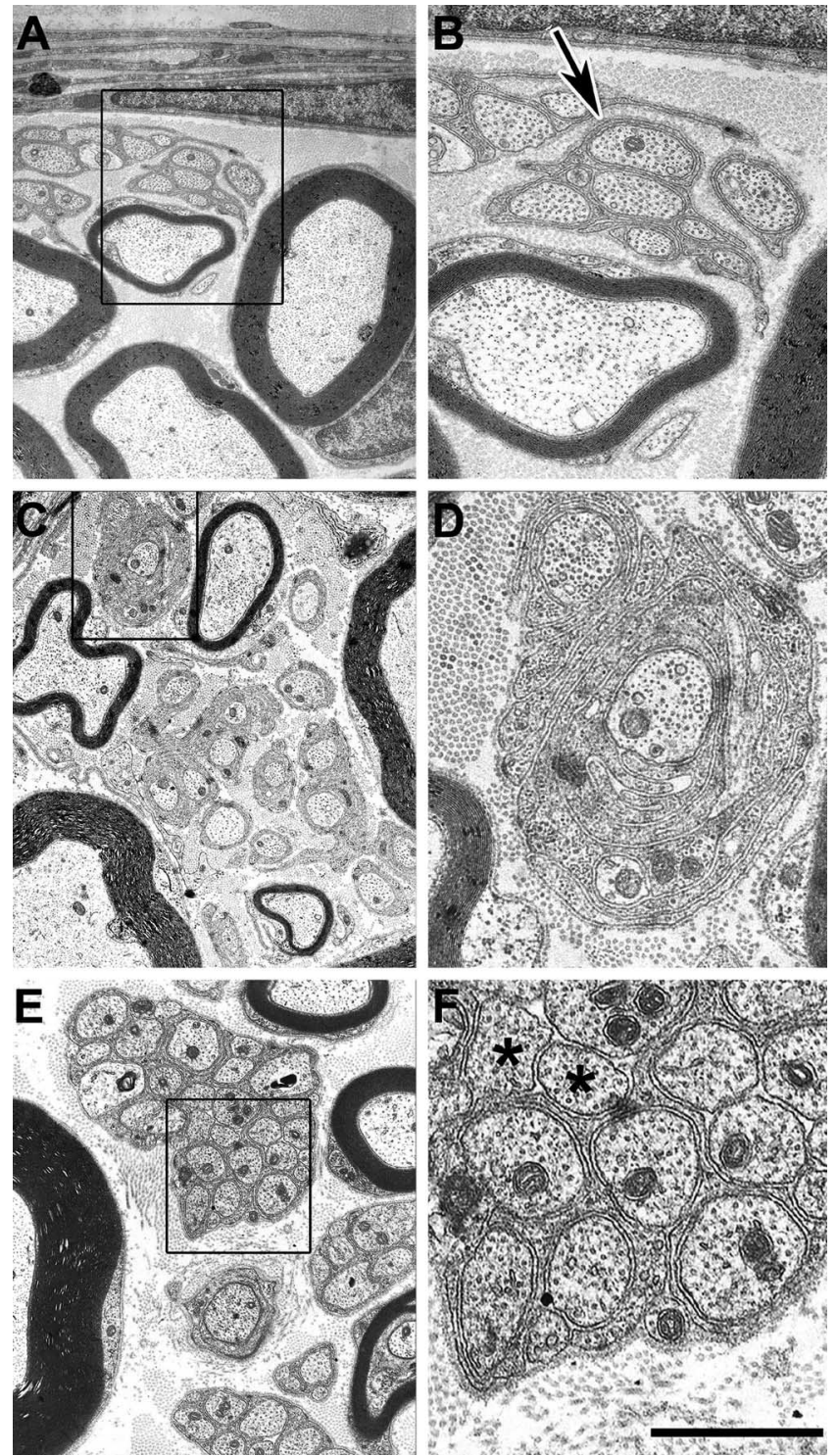

Figure 1. Ultrastructural abnormalities of nonmyelinated fibers in mice overexpressing mutated schwannomin $\mathrm{SCH}-\Delta 39-121$ and $\mathrm{SCH}-\Delta \mathrm{Cter}$. Electron micrographs from sections of phrenic nerves from 12-month-old wild-type $(\boldsymbol{A}, \boldsymbol{B}), \mathrm{PO}-\mathrm{SCH}-\Delta 39-121(\boldsymbol{C}, \boldsymbol{D})$, and P0 - SCH $\Delta$ Cter $(\boldsymbol{E}, \boldsymbol{F})$ mice. In wild-type mice, unmyelinated fibers are each surrounded by a single Schwann cell process ( $\boldsymbol{B}$, arrow). In $\mathrm{P} 0-\mathrm{SCH}-\Delta 39-121$ mice, some unmyelinated small fibers are surrounded by several wraps of Schwann cell process $(\boldsymbol{D})$. In $\mathrm{PO}-\mathrm{SCH}-\Delta$ Cter mice, the endoneurial space encloses partially undefasciculated bundles of unmyelinated axons surrounded by the same process ( $\boldsymbol{F}$, asterisks). Scale bar, $20 \mu \mathrm{m}$.

mally enriched in juxtaparanodes (Poliak et al., 2001), which are differentiated regions of internodes flanking the paranodes. Caspr2 distribution was altered, and its intensity appeared diminished in both $\mathrm{P} 0-\mathrm{SCH}-\Delta 39-121$ and $\mathrm{P} 0-\mathrm{SCH}-\Delta$ Cter mice 
A
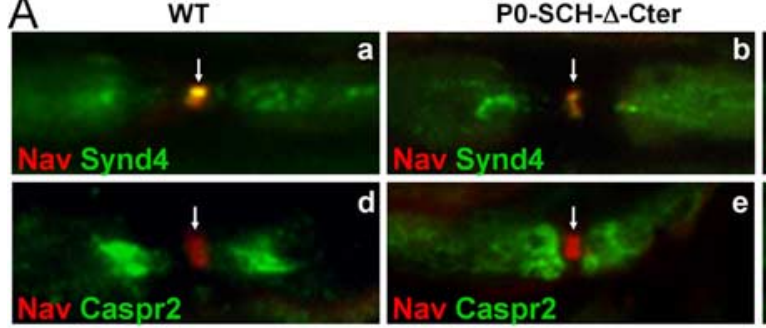

B
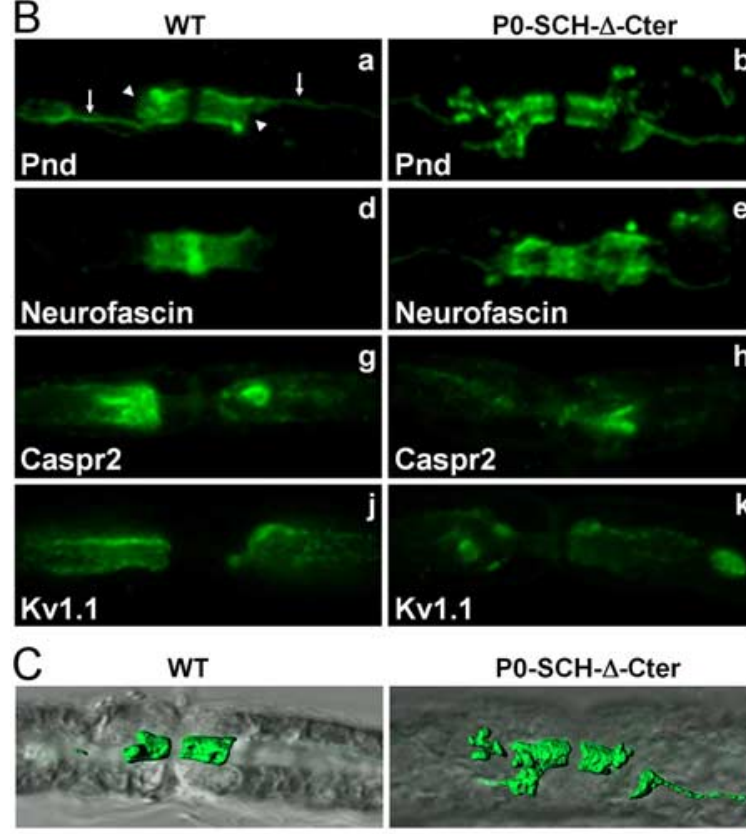

Pnd
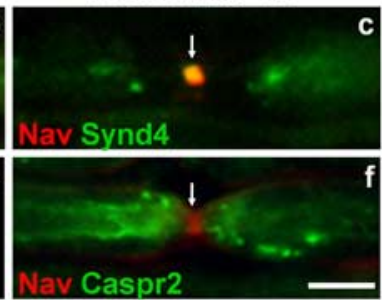

P0-SCH- $\Delta-39-121$
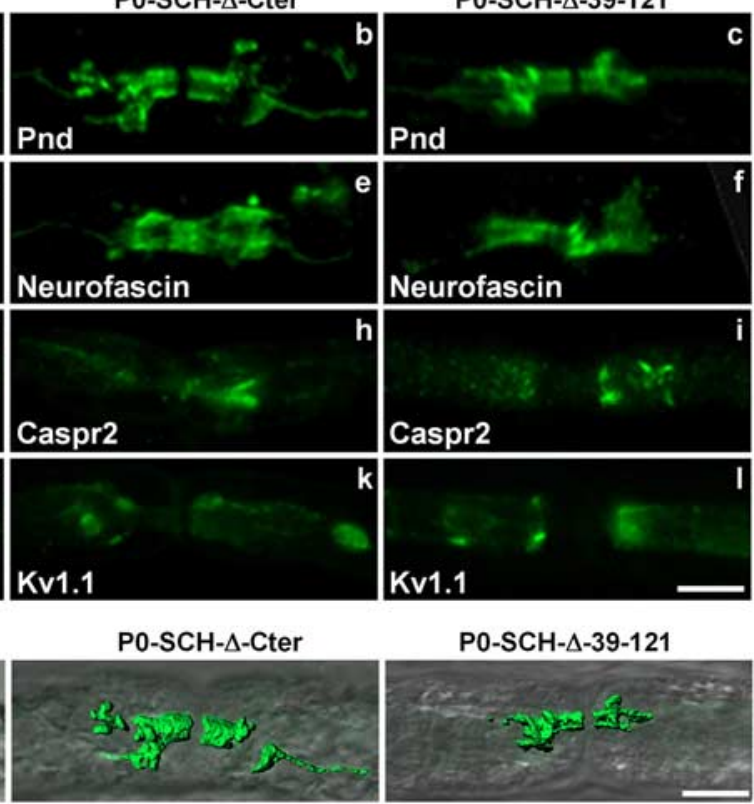

$\mathrm{PO}-\mathrm{SCH}-\triangle-39-121$
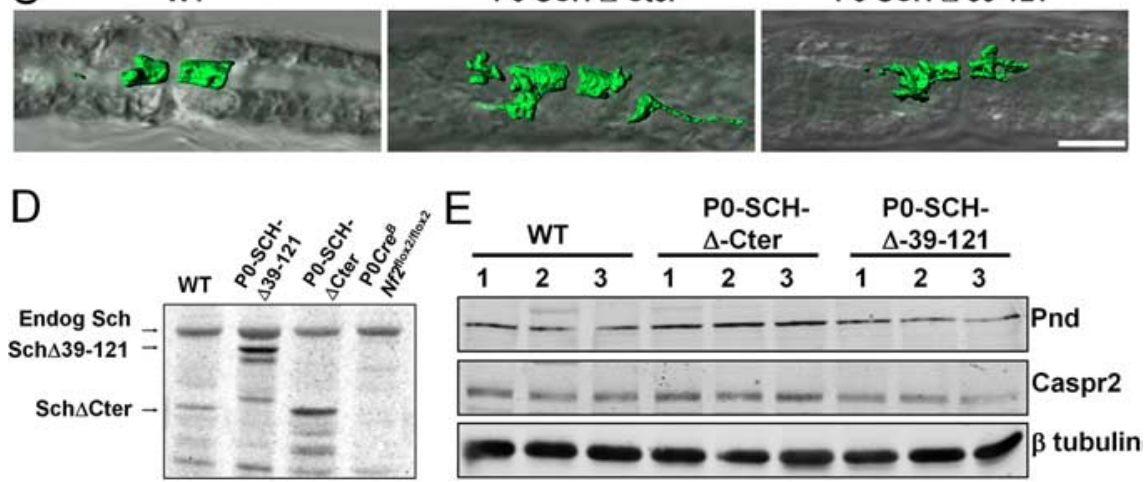

Figure 2. Nodal, paranodal, and juxtaparanodal proteins in the sciatic nerves of mice overexpressing mutated schwannomin. $\boldsymbol{A}$, Immunolocalization of voltage-gated $\mathrm{Na}^{+}$channels ( $\boldsymbol{a}-\boldsymbol{f}$, Nav, in red), syndecan 4 ( $\boldsymbol{a}-\boldsymbol{c}$, Synd4, in green), and Caspr2 ( $\boldsymbol{d}-\boldsymbol{f}$, in green) were examined on longitudinal sections of sciatic nerves from wild-type (WT), $\mathrm{P} 0-\mathrm{SCH}-\Delta \mathrm{Cter}$, and $\mathrm{P0}-\mathrm{SCH}-\Delta 39-121$. Nav and Synd 4 are correctly localized in the nodal regions of the mutant mice. In contrast, Caspr 2 immunoreactivity is irregular in mutant mice compared with wild-type mice. In some cases, Caspr2 labeling extends into the paranodal regions and comes in contact of the nodal marker Nav. $\boldsymbol{B}$, Immunolocalization of paranodin $\left(\boldsymbol{a}-\boldsymbol{c}\right.$, Pnd), neurofascin $(\boldsymbol{d}-\boldsymbol{f})$, Caspr2 $(\boldsymbol{g}-\boldsymbol{i})$, and Kv1.1 $\mathrm{K}^{+}$ channels $(\boldsymbol{j}-\boldsymbol{I})$ was examined on teased fibers of sciatic nerves from wild-type (WT), $\mathrm{PO}-\mathrm{SCH}-\Delta \mathrm{Cter}$, and $\mathrm{PO}-\mathrm{SCH}-\Delta 39-121$ mice. The abnormalities in the distribution of the paranodal (Pnd, Neurofascin) and juxtaparanodal (Caspr2, Kv1.1) proteins are similar to those observed on sciatic nerve sections. $C$, Three-dimensional reconstructions of paranodin immunoreactivity (in green) in teased fibers of sciatic nerves from wild-type (WT), $\mathrm{PO}-\mathrm{SCH}-\Delta \mathrm{Cter}$, and $\mathrm{PO}-\mathrm{SCH}-\Delta 39-121$ mice, combined with the differential interference contrast (in gray). Images reveal the irregular and fragmented organization of the paranodes in mutant mice. D, Left, Protein levels of endogenous schwannomin (Sch) and of mutated forms of schwannomin in sciatic nerves of wild-type, $\mathrm{PO}-\mathrm{SCH}-\Delta 39-121, \mathrm{PO}-\mathrm{SCH}-\Delta \mathrm{Cter}$, and $\mathrm{POCre} ; \mathrm{Nf}^{\text {flox2/ffox }}{ }^{2}$ mice. The mutated forms of schwannomin are expressed at higher levels than the endogenous schwannomin in both mutants. Endogenous schwannomin levels were not diminished in mice with a conditional deletion because the deletion was limited to Schwann cells. Right, Paranodin (Pnd), Caspr2, and neuronal class III $\beta$-tubulin ( $\beta$-tubulin) in sciatic nerves from wild-type (WT), PO $-\mathrm{SCH}-\Delta \mathrm{Cter}$, and $\mathrm{P} 0-\mathrm{SCH}-\Delta 39-121$ mice. Immunoblots were performed on lysates of sciatic nerves obtained from three different mice of each genotype (lanes 1-3) with specific primary antibodies, developed and quantified using the LI-COR Biosciences technology (Odyssey). $\beta$-Tubulin immunoreactivity was used to normalize the amount of loaded protein. The levels of paranodin as well as those of Caspr2 are virtually unchanged in $\mathrm{P0}-\mathrm{SCH}-\Delta 39-121$ and increased (by $170 \%$ for paranodin and $56 \%$ for Caspr2) in P0 $-\mathrm{SCH}-\Delta$ Cter mice. Scale bars: $\boldsymbol{A}-\boldsymbol{C}, 5 \mu \mathrm{m}$. $\boldsymbol{A}$, Images acquired using a Leica epifluorescence microscope. $\boldsymbol{B}$, Single-scan confocal images. compared with wild-type mice (Fig. 2 Ad$A f, B g-B i)$. Areas of strong labeling alternated with almost negative patches, and the labeled regions were usually smaller and less intensely stained than in wild-type mice. At many nodes, Caspr2 labeling extended into the paranodal regions and came in contact of nodal markers (Fig. $2 A e, A f)$. Similar abnormalities were observed for Kv1.1 shaker-type $\mathrm{K}^{+}$channels, which are normally enriched in the juxtaparanodal axonal membrane (Wang et al., 1993) (Fig. 2Bj-Bl). The distribution of paranodal and juxtaparanodal proteins displayed the same abnormalities in 3- and 6-month-old mutant mice as in 1-year old animals (data not shown), indicating that these perturbations were not age dependent.

We evaluated the levels of expression of the endogenous and mutated forms of schwannomin in sciatic nerves extracts from wild-type and transgenic mice. Endogenous schwannomin expression was not diminished in mutant mice, and the levels of expression of mutated schwannomin were higher than those of the endogenous protein in both $\mathrm{P} 0-\mathrm{SCH}-\Delta 39-$ 121 and in $\mathrm{P} 0-\mathrm{SCH}-\Delta$ Cter mice (Fig. $2 D)$. To determine whether the altered immunoreactivity of paranodal and juxtaparanodal proteins resulted from a reduction in their levels of expression, we then examined the levels of paranodin/ Caspr and Caspr2 in sciatic nerve extracts, using $\beta$-tubulin as a control for loading (Fig. 2E). The levels of paranodin and Caspr2 were virtually unchanged in $\mathrm{P} 0-$ $S C H-\Delta 39-121$ and were slightly increased in $\mathrm{P} 0-\mathrm{SCH}-\Delta$ Cter mice (Fig. $2 E$ ). Thus, the abnormalities in the distribution of the paranodal and juxtaparanodal proteins could be related directly to the overexpression of the mutated forms of schwannomin.

\section{Overexpression of mutated}

schwannomin in Schwann cells alters the ultrastructure of paranodal regions We then used electron microscopy to determine whether the abnormalities observed by immunofluorescence corresponded to alterations in the ultrastructure of axoglial contacts. Ten nodes of Ranvier were examined in longitudinal sections of sciatic nerves from two 12month-old mice of each genotype. In wildtype mice, the paranodal myelin loops were tightly and regularly positioned at paranodes, with a symmetrical organization across the heminode (Fig. $3 A$ ), and transverse bands, the ultrastructural hallmark of paranodal junctions, were clearly visible (Fig. 3B, arrowheads). In contrast, 
abnormal paranodal loops and interactions between axons and Schwann cells were frequently observed in mutant mice. Paranodal myelin loops were often asymmetrical in $\mathrm{P} 0-\mathrm{SCH}-\Delta 39-121$ and $\mathrm{P} 0-$ $\mathrm{SCH}-\Delta$ Cter mice with variable width, appearing either enlarged or shrunk from place to place (Fig. 3C-F). Enlarged loops, generally located close to the juxtaparanode (Fig. 3C, arrow), were observed in 33 and $46 \%$ of the heminodes in $\mathrm{P} 0-\mathrm{SCH}-$ $\Delta 39-121$ and $\mathrm{P} 0-\mathrm{SCH}-\Delta \mathrm{Cter}$ mice, respectively. Loop width was more variable in the two lines of mutant mice than in wild-type mice (Fig. 4). Electron-dense transverse bands were visible at the level of the normal loops (Fig. 3C, inset, arrowheads) but were absent from those that were massively enlarged (Fig. 3C, arrow). Atrophic loops, filled with electron-dense material and devoid of transverse bands, were observed in $77 \%$ of the heminodes examined in $\mathrm{P} 0-\mathrm{SCH}-\Delta 39-121$ mice but not in wild-type or $\mathrm{P} 0-\mathrm{SCH}-\Delta$ Cter mice (Fig. 3D). Formations similar to axon Schwann cell networks (Gatzinsky et al., 1991), in which axonal digitations protruded within large glial formations, were observed in mutant (Fig. 3E,F, arrows) but not in wild-type mice. Other features of mutant paranodes included protrusions of Schwann cell cytoplasm into the axon ( $\mathrm{P} 0-\mathrm{SCH}-$ $\Delta 39-121, \quad 22 \%$ of the heminodes; $\mathrm{P} 0-\mathrm{SCH}-\Delta$ Cter, $14 \%$ of the heminodes) or axonal protrusions, bulging out of the axon limits into the cells (P0-SCH- $\Delta 39-121,22 \%$ of the heminodes; $\mathrm{P} 0-\mathrm{SCH}-\Delta \mathrm{Cter}, 36 \%$ of the heminodes). Overall, only $22 \%$ of the heminodes were devoid of the features described above in $\mathrm{P} 0-\mathrm{SCH}-$ $\Delta 39-121$ and $28 \%$ in $\mathrm{P} 0-\mathrm{SCH}-\Delta$ Cter mice, whereas they were not observed in heminodes from matched wild-type mice. Similar features, in approximately the same proportions, were found in sciatic nerves from 3-and 6-month old mice, indicating that they were not secondary to a late degeneration of fibers.

\section{Conditional deletion of schwannomin in Schwann cells alters axoglial contacts}

The results obtained in transgenic mice demonstrated that the targeted overexpression of mutated schwannomin in Schwann cells resulted in a marked disorganization of axoglial contacts. Importantly, many alterations found in $\mathrm{P} 0-\mathrm{SCH}-\Delta 39-121$ mice were also observed in $\mathrm{P} 0-\mathrm{SCH}-\Delta$ Cter transgenic mice, albeit to a slightly lesser degree. Such alterations could theoretically result from a gain of function of mutated proteins or from a partial or complete loss of function with a dominant-negative effect. The similar phenotype of the two different mutations argued in favor of the second hypothesis. To distinguish more precisely between these two hypotheses, we used mutant mice in which NF2 exon 2 was conditionally deleted in Schwann cells (P0Cre;Nf2 flox2/flox2) (supplemental Fig. 1, available at www.jneurosci.org as supplemental material). The line we used $\left(\mathrm{PO}-\mathrm{Cr} \mathrm{e}^{B}\right)$ had no major postnatal lethality, in contrast with the initially reported $\mathrm{PO}-\mathrm{Cr} \mathrm{e}^{A}$ line (Giovannini et al., 2000), allowing the study of the peripheral nervous system in adult mice. In these mice, a large proportion of

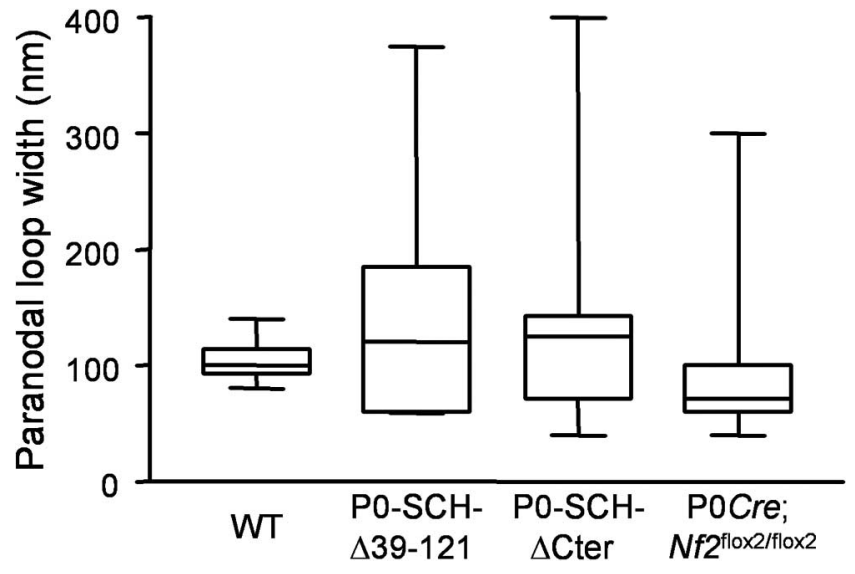

Figure 4. Quantification of paranodal loop width in sciatic nerves from wild-type (WT), $\mathrm{PO}-\mathrm{SCH}-\Delta 39-121, \mathrm{PO}-\mathrm{SCH}-\Delta \mathrm{Cter}$, and $\mathrm{POCre} ; \mathrm{Nf}^{\text {flox2/flox2 }}$ mice. The width of 10 adjacent paranodal loops was measured in 10 heminodes for each genotype. Loop width was more variable in the three lines of mutant mice than in wild-type mice. Loop-like structures with width $>400 \mathrm{~nm}$ were not included. Minimum, $25 \%$ percentile, median, $75 \%$ percentile, and maximum are indicated.

Schwann cells is devoid of schwannomin, because deletion of exon 2 destabilizes the molecule (Giovannini et al., 2000). However, the total amount of schwannomin in sciatic nerve homogenates was not decreased (Fig. 2D) because the deletion occurred in Schwann cells, whereas the protein is also expressed in other cell types, including axons (Denisenko-Nehrbass et al., 2003). 


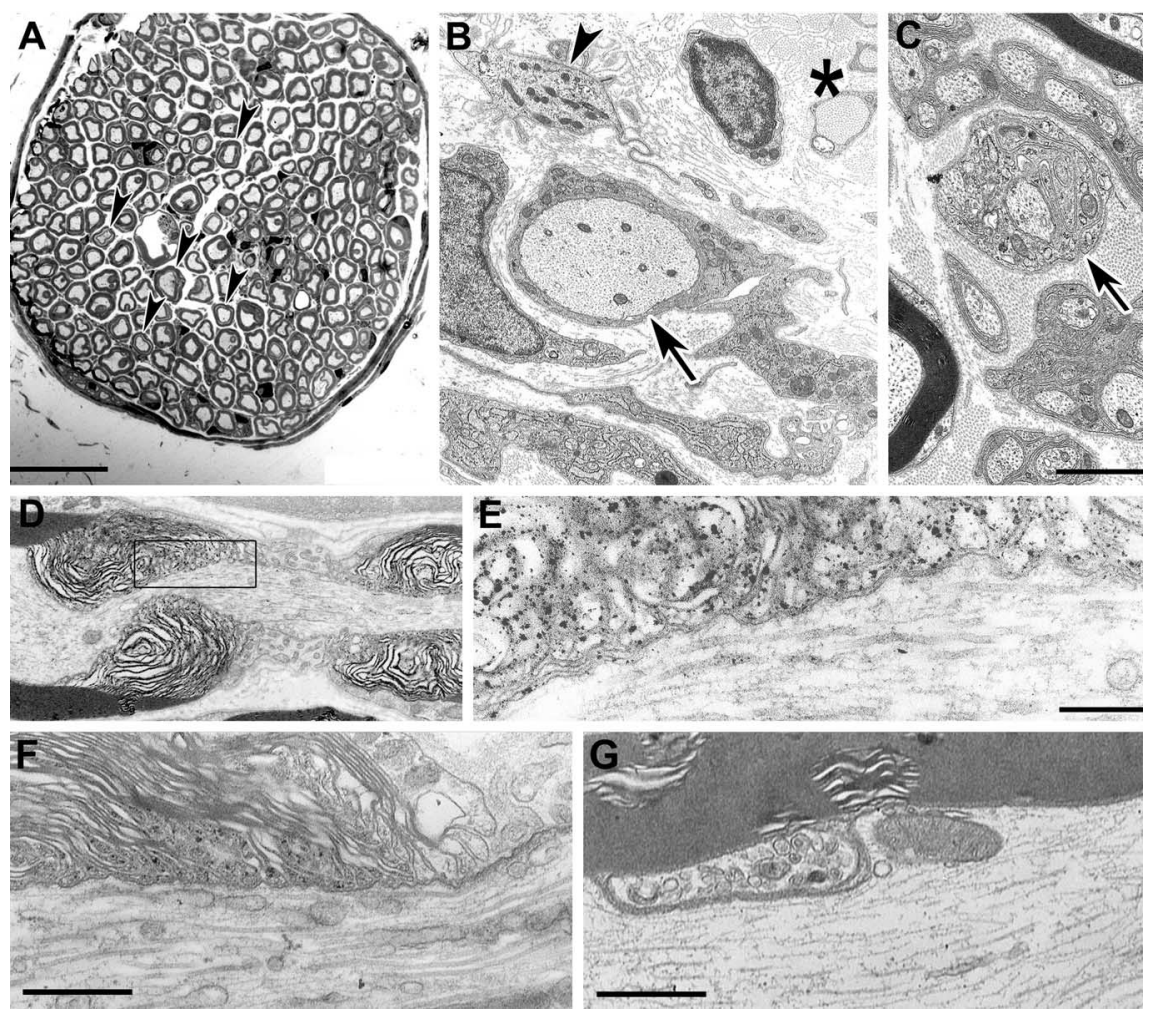

Figure 5. Structural abnormalities in peripheral nerves from 12-month-old POCre; $N f 2^{\text {floxz } / f l o x 2}$ mice. $\boldsymbol{A}$, Transversal semithin section of a phrenic nerve showing an increase of the endoneurial space between myelinated fibers and the presence of concentric myelin rings corresponding to Schmidt-Lanterman incisures (arrowheads). Scale bar, $20 \mu \mathrm{m}$. B, C, Electron micrographs from phrenic nerve transverse sections showing a regenerative fiber ( $\boldsymbol{B}$, arrow), a collapsed Schwann cell ( $\boldsymbol{B}$, arrowhead), a collagen pocket ( $\boldsymbol{B}$, asterisk), and a small axon surrounded by multiple wraps of nonmyelinating $S$ chwann cells ( $\boldsymbol{C}$, arrow). Scale bar, $1 \mu \mathrm{m}$. D-G, Electron micrographs from longitudinal sections of nodes of Ranvier of sciatic nerve showing paranodal regions with irregular paranodal loops enclosing electron-dense material and lacking transverse bands $(\boldsymbol{E}, \boldsymbol{F})$ and enlarged loop-like structures, containing vesicular material (G). Scale bars, $2 \mu \mathrm{m}$.

In $\mathrm{P} 0 \mathrm{Cr} e^{B} ; \mathrm{Nf} 2^{\text {flox2/flox2 }}$ mice, analysis of semithin sections of sciatic nerve (Fig. $5 A$ ) showed a slight decrease $(-12 \%)$ in the number of myelinated fibers (Table 1 ) compared with wild-type mice. The myelin thickness was slightly increased as indicated by a minor decrease in the G-ratio (Table 1). Electron microscopy of phrenic nerve sections showed some indirect evidence of axonal loss in $\mathrm{POCre}{ }^{B} ; \mathrm{Nf2} 2^{\text {flox2/flox2 }}$ mice, including collagen pockets in the endoneurial space, fibers, and collapsed Schwann cells (Fig. 5B, asterisk, arrow, and arrowhead, respectively). Abnormal Schwann cell wrapping was evidenced by small axons surrounded by multiple wraps of nonmyelinating Schwann cells (Fig. 5C, arrow) and by bundles of undefasciculated small axons wrapped by a myelinating Schwann cell (data not shown). Thus, these mice displayed signs of moderate axonal loss and aberrant myelination.

Electron microscopic study of longitudinal sections of sciatic nerves, at the level of nodes of Ranvier, revealed abnormalities of paranodes. The size of adjacent loops was irregular (Fig. 4). Atrophic paranodal loops (22\%) and axonal protrusions (11\%), sometimes with electron-dense material, were also present (Fig. $5 D-F)$. Transverse bands were not visible at the level of these altered paranodal loops (Fig. $5 E, F$ ). Enlarged paranodal loops and axon Schwann cell networks containing mitochondria and other vesicular material were frequently observed ( $44 \%$ of the heminodes), generally located close to the juxtaparanode (Fig. $5 G)$ (data not shown).

We examined molecular markers of nodal regions in sections and teased fibers of sciatic nerves from $\mathrm{P} 0 \mathrm{Cr} e^{B} ; \mathrm{Nf} 2^{\text {flox2/flox2 }}$ mice. There was no consistent difference in the distribution of proteins enriched in the nodal axon, including sodium channels (Fig. 6Aa-Ad) and proteins of glial microvilli syndecan 3 (data not shown) and 4 (Fig. 6Ac,Ad). In contrast, the distribution of the paranodal and juxtaparanodal markers was severely altered (Fig. 6B). Paranodin/caspr immunoreactivity was distributed irregularly, with a combination of areas of normal and decreased labeling, often not delineating paranodal regions and invading the nodal or juxtaparanodal spaces (Fig. $6 B a, B b$ ). We noticed that paranodin immunoreactivity was more frequently altered in large fibers than in small ones. The threedimensional reconstructions further indicated the overall alterations of paranodin distribution (Fig. 6C). The labeling of paranodal neurofascin was less regular in P0Cre;Nf2 ${ }^{\text {flox2/flox } 2}$ than in wild-type mice, and its overall intensity was dramatically reduced (Fig. $6 \mathrm{~B}$ ), as confirmed by quantification (wild type, $61 \pm 5$; mutant, $28 \pm$ 3 ; mean \pm SEM, arbitrary units; $n=5$; $t$ test, $p<0.00035)$. Caspr2 immunoreactivity was also decreased, irregular, and abnormally located, often in contact with the nodal proteins (Fig. 6B). Kv1.1 immunoreactivity was similarly altered (data not shown). However, immunoblotting experiments on sciatic nerve extracts showed that the levels of paranodin as well as those of Caspr2 were virtually unchanged in P0Cre; $f 2^{\text {flox } 2 / f l o x 2}$ mice (Fig. $6 D$ ), indicating that the alterations of immunoreactivity of the paranodal and juxtaparanodal proteins did not correspond to changes in their levels of expression. Thus, mice bearing a targeted deletion of schwannomin in Schwann cells displayed severe alterations of the organization of axoglial contacts.

\section{Mutation of schwannomin in Schwann cells alters the number of Schmidt-Lanterman incisures, the internodal length, and the number of Schwann cells}

The compact myelin in Schwann cells is regularly interrupted by SLIs, which are helicoidal cytoplasmic channels thought to facilitate the communication between the cytoplasmic compartments on adaxonal and abaxonal sides of the myelin sheath. These incisures are characterized by the presence of Schwann cell autotypic contacts, including adherens junctions, tight junctions, and gap junctions, containing cadherins, claudins, and connexins, respectively (Arroyo and Scherer, 2000). On transverse sections, SLIs can appear as an empty space between double concentric myelin rings (Robertson, 1958). While studying transverse sections of phrenic nerves of P0Cre; Nf2 flox2/flox2 mice, we noticed that myelin sheaths appeared more frequently as double concentric myelin rings than in wild-type mice (Fig. $5 A$ ), suggesting an increased number of SLIs. We counted the number of fibers with double concentric rings on transverse phrenic nerve sections (Table 1). Their number was significantly higher in $\mathrm{P} 0-\mathrm{SCH}-\Delta 39-$ 121 and $\mathrm{P} 0 \mathrm{Cre}$; $\mathrm{Nf} 2^{\text {flox2/flox2 }}$ mice compared with wild-type or P0- 

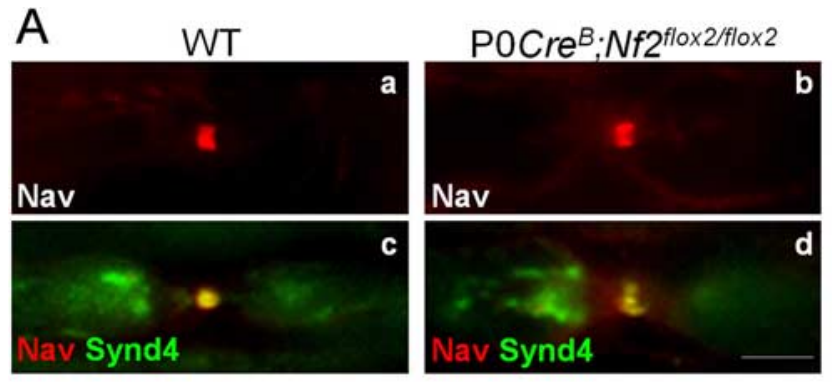

B
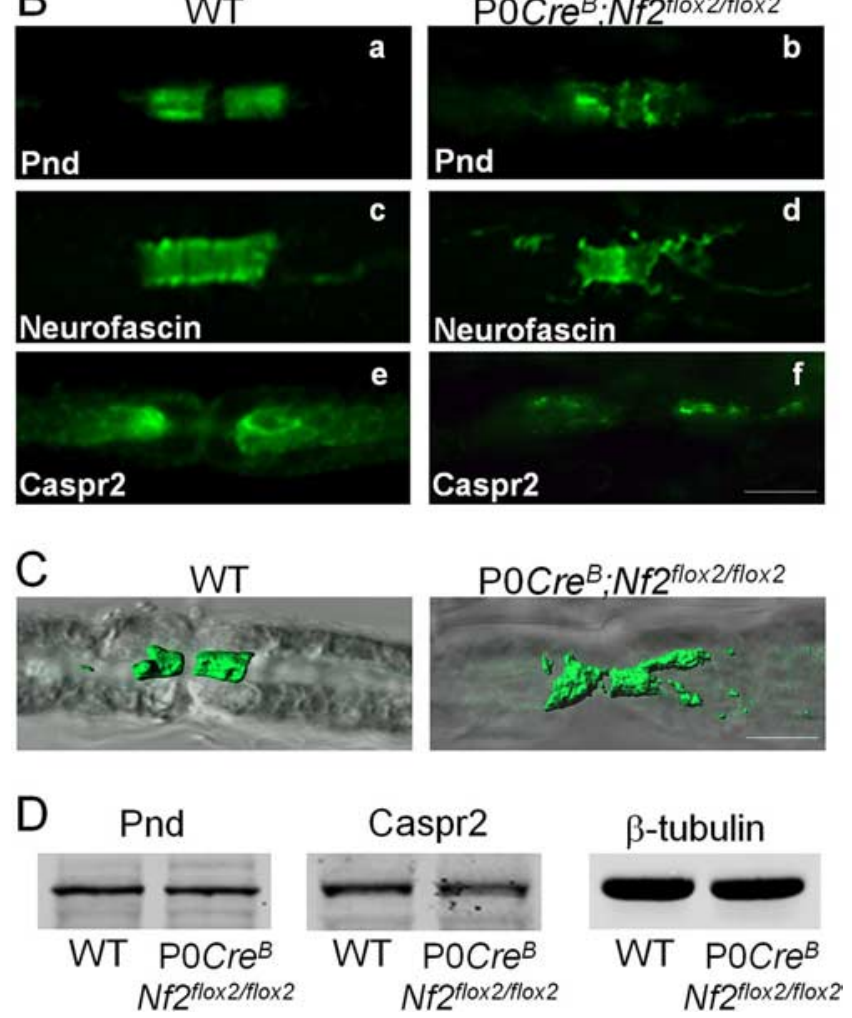

Figure 6. Immunolocalization and expression of nodal, paranodal, and juxtaparanodal proteins in the sciatic nerves of POCre; $N f 2^{\text {floxz }}{ }^{\text {flox }}$ mice. $A$, Immunolocalization of voltage-gated $\mathrm{Na}^{+}$channels ( $\boldsymbol{a}-\boldsymbol{d}, \mathrm{Nav}$, in red) and syndecan 4 ( $\boldsymbol{c}, \boldsymbol{d}$, Synd4, in green) was examined on longitudinal sections of sciatic nerves from wild-type (WT) and POCre; Nf2 ${ }^{\text {flox2 } 2 \text { flox2 }}$ mice. Nav and Synd 4 are correctly segregated in the nodal regions. $\boldsymbol{B}$, Immunolocalization of paranodin/Caspr (Pnd), neurofascin $(\boldsymbol{a}, \boldsymbol{b})$ and Caspr2 $(\boldsymbol{c}, \boldsymbol{d})$ in teased fibers of sciatic nerves from wild-type (WT)

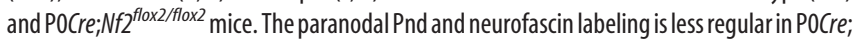
$\mathrm{Nf2}{ }^{\text {flox2/flox2 }}$ than in wild-type mice, and its overall intensity is reduced. Caspr2 immunoreactivity is also decreased and irregular. C, Three-dimensional reconstructions of paranodin immunoreactivity (in green) in teased fibers of sciatic nerves from wild-type (WT) and POCre; $N 2^{\text {flox2/flox2 }}$ mice, combined with the differential interference contrast (in gray). The image reveals the irregular distribution of paranodin invading the juxtaparanodal and nodal regions. $\boldsymbol{D}$, Protein expression levels of paranodin (Pnd), Caspr2, and neuronal class III $\beta$-tubulin ( $\beta$-tubulin) in sciatic nerves from wild-type (WT) and POCre; $\mathrm{Nf}^{\text {flox2/flox2 }}$ mice. Immunoblots were performed on lysates of sciatic nerves with specific primary antibodies, developed, and quantified using the LI-COR Biosciences technology (0dyssey). $\beta$-Tubulin immunoreactivity was used to normalize the amount of loaded protein. The levels of paranodin and Caspr2 are unchanged in POCre; $N f 2^{\text {flox2/flox2 }}$ mice. Scale bars: $\boldsymbol{A}-\boldsymbol{C}, 5 \mu \mathrm{m}$. $\boldsymbol{A}$, Images acquired using a Leica epifluorescence microscope. $\boldsymbol{B}$, Single-scan confocal images.

SCH- $\Delta$ Cter mutant mice (Table 1 ). This increased number of double concentric rings was observed in 3-, 6-, and 12-monthold mutant mice (data not shown). To quantify precisely the number of SLIs per Schwann cells in mutant mice, we measured internodal lengths and distances between adjacent SLIs (visualized by $\beta$-catenin immunostaining) on teased sciatic fibers (Fig.
$7 A)$. A characteristic feature of two of the mutant mouse lines was an increased proportion of very short internodes $(<350 \mu \mathrm{m})$, which was significantly higher in $\mathrm{P} 0-\mathrm{SCH}-\Delta 39-121$ transgenic mice $(22 \%)$ and $\mathrm{P} 0 \mathrm{Cre} ; \mathrm{Nf} 2^{\text {flox } 2 / f l o x 2}$ mice $(63 \%)$ than in $\mathrm{P} 0-\mathrm{SCH}-$ $\Delta$ Cter $(0 \%)$ or wild-type $\left(4 \% ; \chi^{2}=35.7 ; p<0.0001\right)$ mice. The average internodal length was not significantly different between wild-type and $\mathrm{P} 0-\mathrm{SCH}-\Delta \mathrm{Cter}$ and $\mathrm{P} 0-\mathrm{SCH}-\Delta 39-121$ transgenic mice but was decreased in P0Cre;Nf2 flox2/flox2 mice (Fig. $7 B$ ). Because a correlation between the caliber of a myelinated axon and the internodal length is well established (Friede, 1983), we normalized internodal distances to axon caliber. Although the average fiber diameter was smaller in $\mathrm{P} 0 \mathrm{Cre} ; \mathrm{Nf} 2^{\text {flox2/flox2 }}$ than in wild-type mice, the internodal distance normalized to axonal diameter was significantly decreased (Fig. 7C,D). The distance between SLIs was also decreased in mutant mice, the diminution being more pronounced in $\mathrm{P} 0-\mathrm{SCH}-\Delta 39-121$ and $\mathrm{P} 0 \mathrm{Cre}$; $N f 2^{\text {flox2/flox2 }}$ than in $\mathrm{P} 0-\mathrm{SCH}-\Delta$ Cter mice (Fig. $7 E$ ), confirming the increased number of SLIs in these mice.

To determine whether an increased proportion of very short internodes and the decreased distance between SLIs observed in $\mathrm{P} 0-\mathrm{SCH}-\Delta 39-121$ mice could be associated with an increased proliferation of Schwann cells at the early onset of myelination, we counted Schwann cell nuclei along teased sciatic nerves derived from postnatal day 1 wild-type, $\mathrm{P} 0-\mathrm{SCH}-\Delta 39-121$, and P0-SCH- $\Delta$ Cter mice (Fig. $7 F, G$ ). At the early onset of the myelination, the number of Schwann cells along the nerve fibers was higher in $\mathrm{P} 0-\mathrm{SCH}-\Delta 39-121$ mice than in wild-type or P0SCH- $\Delta$ Cter mice (Fig. $7 F, G$ ). Importantly, the number of Schwann cells was not altered in $\mathrm{P} 0-\mathrm{SCH}-\Delta$ Cter mice. We also looked for alterations in the number of Schwann cells in P0Cre; $\mathrm{Nf} 2^{\text {flox2/flox2 }}$ using 3-month-old mice (Fig. $7 \mathrm{H}, I$ ). At this age, the cell density was much lower than in neonates. In wild-type mice, the Schwann cell nuclei were isolated and never in close vicinity of the node. In contrast, in P0Cre; Nf $2^{\text {flox2/flox2 }}$ mice, we often observed pairs of nuclei, close to the nodal region (Fig. $7 H$, right panel, arrows). Cell counts showed that the number of nuclei per length of fiber was significantly increased (Fig. 7I). These observations clearly supported the hypothesis of an increased number of Schwann cells during myelination in $\mathrm{P} 0-\mathrm{SCH}-\Delta 39-12$ and $\mathrm{P} 0 \mathrm{Cre} ; \mathrm{Nf} 2^{\text {flox2/flox2 }}$ but not in $\mathrm{P} 0-\mathrm{SCH}-\Delta$ Cter mice.

We also measured, by immunoblotting, the amounts of $\beta$-catenin and NF155, the $155 \mathrm{kDa}$ glial isoform of neurofascin, two proteins enriched in SLIs (Fannon et al., 1995; Chang et al., 2000). The levels of these two proteins were increased in sciatic nerve extracts from the three lines of mutant mice compared with wild-type mice (Fig. 7J). Altogether, these results show that the number of SLIs is altered by mutations in schwannomin and that overexpression of $\mathrm{P} 0-\mathrm{SCH}-\Delta 39-121$ or conditional knock-out of schwannomin decreases the internodal length, i.e., increases the number of myelinating Schwann cell per length unit of axon.

\section{Discussion}

Our observations in mice overexpressing specifically mutated schwannomin in Schwann cells, under the control of P0 promoter, demonstrate an important role of this protein in the organization of axoglial interactions and Schwann cell autotypic contacts at the level of SLIs. It was shown previously that mice overexpressing SCH- $\Delta 39-121$, but not those overexpressing $\mathrm{SCH}-\Delta$ Cter, display Schwann cell hyperplasia and develop tumors (Giovannini et al., 1999). These findings were confirmed in mice with a selective deletion of schwannomin in Schwann cells (Giovannini et al., 2000). These previous observations, as well as those from other mutant mice (McClatchey et al., 1998) and a 


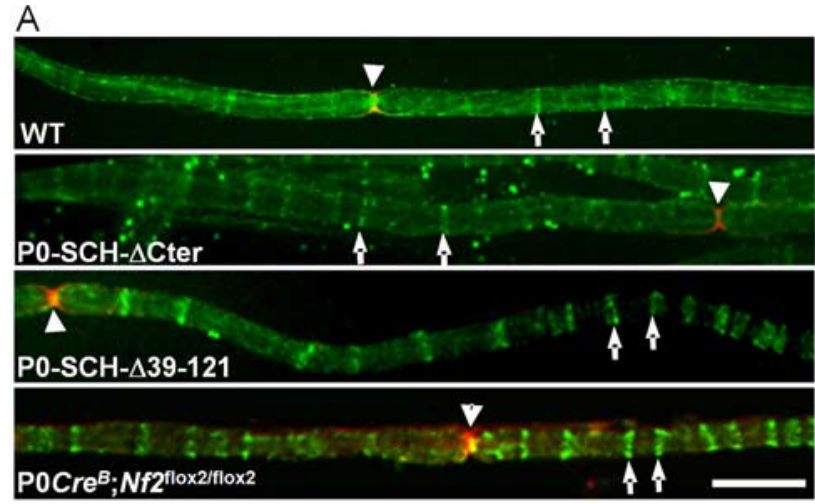

B

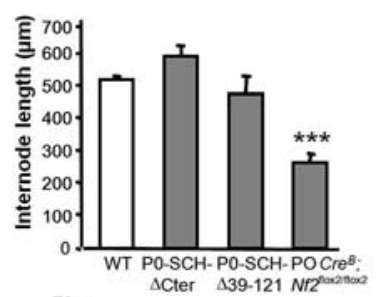

$\mathrm{D}$
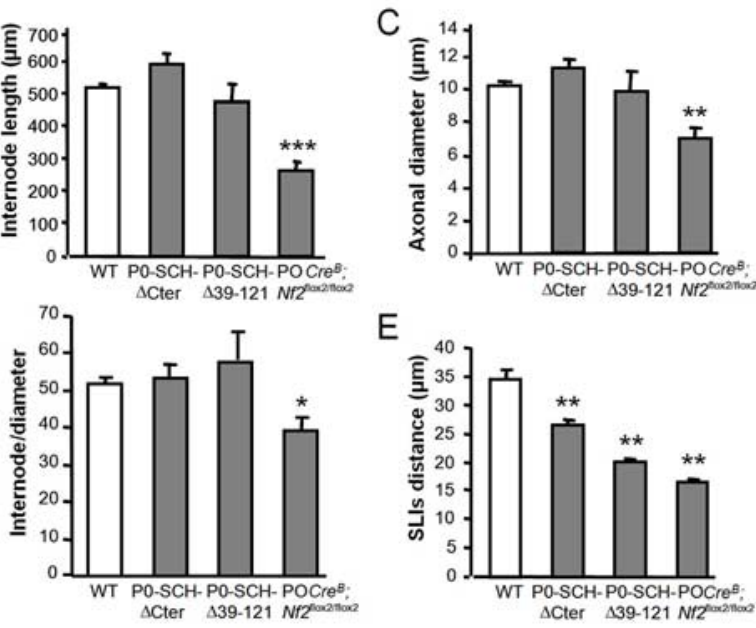

E

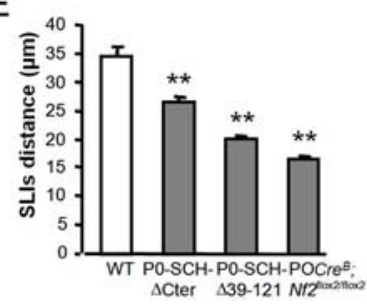

$\mathrm{F}$
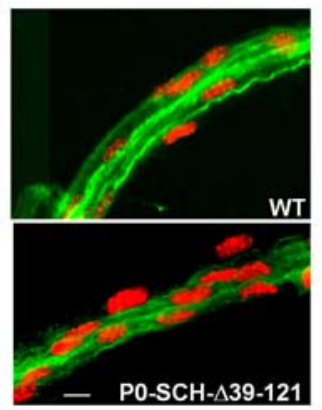

G

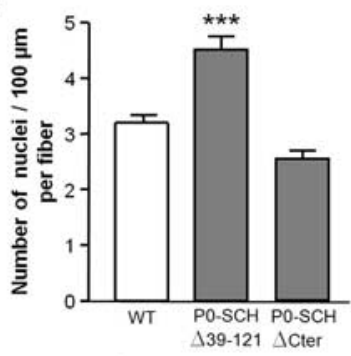

$\mathrm{PO}-\mathrm{SCH}-\triangle 39-121$

$\mathrm{H}$
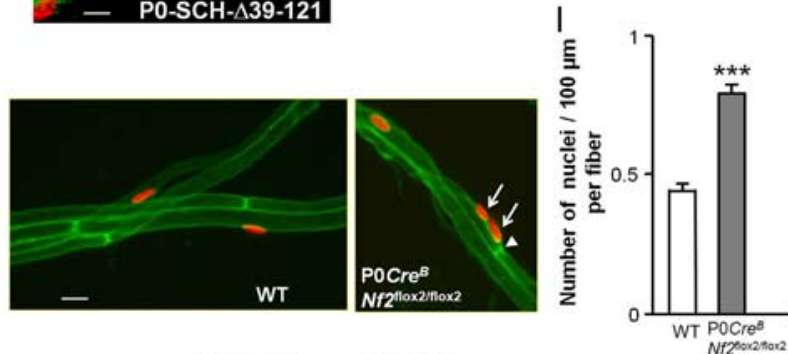

$\mathrm{J}$

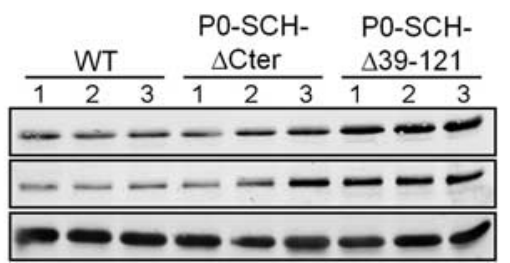

$\mathrm{POCre}$. WT Nf2 flox 2 ffiox2

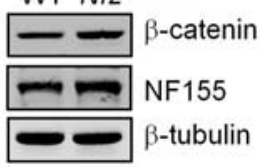

Figure 7. Alteration of the number of Schmidt-Lanterman incisures and abnormal internodal length in the myelinated fibers of $\mathrm{PO}-\mathrm{SCH}-\Delta 39-121, \mathrm{PO}-\mathrm{SCH}-\Delta \mathrm{Cter}$, and $\mathrm{POCre}$; $N f 2^{\text {flox2/flox2 }}$ mice. $A$, Visualization of Schmidt-Lanterman incisures and nodes in teased fibers from sciatic nerves of wild-type (WT), $\mathrm{P} 0-\mathrm{SCH}-\Delta \mathrm{Cter}, \mathrm{P} 0-\mathrm{SCH}-\Delta 39-121$, and POCre; $\mathrm{Nf} 2^{\text {flox2/flox2 }}$ mice. Nodes are delimited by voltage-gated $\mathrm{Na}{ }^{+}$channels immunolabeling (in red, arrowheads), whereas $S c h m i d t-L a n t e r m a n$ incisures are revealed by $\beta$-catenin labeling (in green, arrows). Scale bar, $25 \mu \mathrm{m}$. $\boldsymbol{B}-\boldsymbol{E}$, Quantifications of the internodal length (B), axonal number of studies in cells in culture (McClatchey and Giovannini, 2005), demonstrated the tumor suppressor activity of schwannomin, providing a basis for the phenotype of patients with NF2. The present study shows that schwannomin is also important for the organization of myelinated fibers.

The phenotype of schwannomin mutant mice included some abnormalities of nonmyelinated fibers, which may be attributable to the expression of $\mathrm{P} 0$ promoter in nonmyelinating Schwann cells (Zhang et al., 1995). A partial deficit in defasciculation of axon bundles by Schwann cells was observed in schwannomin mutants. Interestingly, it has been shown recently that focal adhesion kinase is involved in defasciculation (Grove et al. 2007), suggesting a possible link with schwannomin that is associated with focal adhesion kinase (FAK) and $\beta 1$-integrins (Taylor et al., 2003) and can alter FAK activity (Poulikakos et al., 2006). Several other features suggested that Schwann cell membrane interactions were altered in schwannomin mutant mice. Nonmyelinating Schwann cell extension wrapped several fold around small axons in $\mathrm{P} 0-\mathrm{SCH}-\Delta 39-121$ and $\mathrm{P} 0 \mathrm{Cre} ; \mathrm{Nf} 2^{\text {flox2/flox2 }}$ mice, instead of stopping after a single turn. Exuberant myelination of large-caliber fibers was reported in a different line of P0Cre; $\mathrm{Nf2} 2^{\text {flox2/flox2 }}$ mice, expressing higher levels of Cre than the line used in this study (Giovannini et al., 1999), and we observed a relative increase in myelin thickness in $\mathrm{P} 0-\mathrm{SCH}-\Delta$ Cter and $\mathrm{P} 0 \mathrm{Cre}$; $\mathrm{Nf} 2^{\text {flox2/floxz }}$ mice. These findings suggest that the inhibitory signals that normally stop the extension of Schwann cell lamellipodia are defective when schwannomin is mutated or deleted. This could be a consequence of the ability of schwannomin to inhibit Pak1-mediated recruitment of Rac to the plasma membrane and matrix adhesions (Shaw et al., 2001; Morrison et al., 2007; Okada et al., 2007). Schwannomin may also have a regulatory role through its interactions with ErbB2 (Fernandez-Valle et al., 2002), a receptor for the axonal factor neuregulin-1, critical for the control of myelin thickness (Garratt et al., 2000; Michailov et al., 2004). Additional signs of altered axon-Schwann cell interactions included the frequent protrusions originating from one cell type into the other, including the formation of axonSchwann cell networks. These complex interactions between axons and Schwann cells have been described in paranodal regions of other species (Gatzinsky et al., 1991). It is striking that we did not observe them in sciatic nerves of wild-type mice but only in

diameter $(\boldsymbol{C})$, the ratio of internodal length to axonal diameter $(\boldsymbol{D})$, and the distance between adjacent Schmidt-Lanterman incisures $(\boldsymbol{E})$, in teased fibers of sciatic nerves from wild-type, $\mathrm{PO}-\mathrm{SCH}-\Delta \mathrm{Cter}, \mathrm{PO}-\mathrm{SCH}-\Delta 39-121$, and POCre; Nf $2^{\text {flox2/floxz }}$ mice. Data are means + SEM. Statistical analysis by one-way ANOVA, followed by Dunnett's multiple comparison test: ${ }^{*} p<$ $0.05 ;{ }^{* *} p<0.01 ;{ }^{* * *} p<0.001$. F, G, At postnatal day 1 , more Schwann cells were aligned along fibers of $\mathrm{PO}-\mathrm{SCH}-\Delta 39-121$ mice than of wild-type or $\mathrm{PO}-\mathrm{SCH}-\Delta$ Cter mice. Schwann cell nuclei were detected with DAPI staining (red) and fibers with anti-neurofilament antibody (green). Scale bar, $10 \mu \mathrm{m}$. Quantification was performed by calculating the number of nuclei per unit of fiber length and divided by the number of axons in the bundle (G). ANOVA: $F_{(2,123)}=$ 15.8; $p<0.0001$. Post hoc Tukey's test: ${ }^{* * *} p<0.001$ compared with wild type. $\boldsymbol{H}, I$, A similar approach was used in 3-month-old POCre; Nf2 ${ }^{\text {flox2/flox2 }}$ mice and wild-type littermate controls. Pairs of nuclei (arrows), sometimes close to a node (arrowhead), were observed in mutant but not wild-type mice; fibers contours are shown with nonspecific antibody (green). Scale bar, $30 \mu \mathrm{m}$. Quantification and statistical analysis by Student's $t$ test: $t=10.7 ; n=153 ;{ }^{* * *} p<0.0001(I)$. $J$, Expression of $\beta$-catenin, NF155, and neuronal class III $\beta$-tubulin ( $\beta$-tubulin) in sciatic nerves from wild-type (WT), PO $\mathrm{SCH}-\Delta$ Cter, $\mathrm{PO}-\mathrm{SCH}-\Delta 39-121$, and POCre; $\mathrm{Nf2}{ }^{\text {flox2/flox2 }}$ mice. Immunoblots were performed on lysates of sciatic nerves with specific primary antibodies, developed, and quantified using the LI-COR Biosciences technology (Odyssey). Left, Immunoblot on lysates from three different mice of each wild-type and transgenic genotype (lines 1-3). Right, Immunoblot on lysates from wild-type and POCre; $\mathrm{Nf} 2^{f t 0 \times 2 / f l o x 2}$ mice. The levels of $\beta$-catenin and NF155 are increased in sciatic

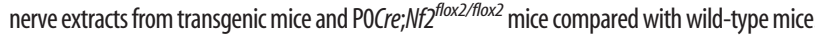


mutant animals. Thus, it is tempting to suggest that their frequent occurrence also resulted from a deficient regulation of Schwann cell membrane expansion.

In contrast with the exuberant axoglial interactions discussed above, we also observed atrophic paranodal loops containing electron-dense material. Thus, a distinctive feature of schwannomin mutant mice was the coexistence of apparently normal loops and loops with an increased size and/or atrophic loops. In these latter two types, transverse bands that are characteristic for intact axoglial contacts were usually not present. The combination of regions of normal and abnormal axoglial junctions provided the basis for the irregular distribution of juxtaparanodal and paranodal proteins, and their extension toward nodes and internodes. This phenotype was different from that described previously in other mutant mice in which the transverse bands were completely absent (Dupree et al., 1999; Bhat et al., 2001; Boyle et al., 2001; Mathis et al., 2001). In these mice, paranodal markers were diffusely distributed along the axon, and juxtaparanodal markers spread through paranodes to the vicinity of nodal markers. These observations provide evidence for an important role of schwannomin in the organization and stability of Schwann cells membrane domains. This role may be related to the partitioning of schwannomin in lipid rafts (Stickney et al., 2004), which are important for the segregation of membrane proteins and organization of axoglial contacts (Schafer et al., 2004).

An increased number of incisures was found in the three Nf2 mutant genotypes, although it was much more striking in P0Cre; $N f 2^{\text {flox } 2 / f l o x 2}$ and, to a lesser degree, $\mathrm{P} 0-\mathrm{SCH}-\Delta 39-121$ mice than in $\mathrm{P} 0-\mathrm{SCH}-\Delta$ Cter mice. A similar increased number of incisures was observed in mutant mice with altered Schwann cell-axon interactions, including myelin basic protein-deficient shiverer mice (Gould et al., 1995), sulfatide-deficient mice (Hoshi et al., 2007), and desert hedgehog-null mice (Sharghi-Namini et al., 2006). In contrast to desert hedgehog-null mice, both shiverer (Sharghi-Namini et al., 2006) and schwannomin mutant mice displayed an increase in $\beta$-catenin and NF155 levels, indicating that these various mutations altered SLI numbers through different mechanisms. Little is known about the regulation of the formation of SLIs in which cadherin-mediated autotypic interactions are a key component (Tricaud et al., 2005; Perrin-Tricaud et al., 2007). Schwannomin immunoreactivity has been reported in SLIs (Scherer and Gutmann, 1996), suggesting that alteration of SLI numbers in schwannomin mutant mice may result from the role of schwannomin in stabilizing cadherin-based adherens junctions (Lallemand et al., 2003). This may involve the associated protein erbin (Rangwala et al., 2005) and Rac1 (Tricaud et al., 2005). In support of this hypothesis, $\beta$-catenin appears to stabilize SLIs through an inhibition of Rac1 (Tricaud et al., 2005) and schwannomin is capable of suppressing the recruitment of Rac1 to the plasma membrane (Okada et al., 2005).

Another conspicuous feature observed in schwannomin mutant mice was the shortening of internodal distances. The shortening of internodal distance was dramatic in P0Cre; $N f 2^{\text {flox2/flox2 }}$ mice, and an increased number of very short internodes was also found in $\mathrm{P} 0-\mathrm{SCH}-\Delta 39-121$ mice. We found that reduced axon caliber could not account for these short internodes. Conversely, cell proliferation and apoptosis are known to control Schwann cell number in the developing peripheral nervous system (Jessen and Mirsky, 2005). Our observation of an increased number of Schwann cells aligned along axons before the onset of myelination in $\mathrm{P} 0-\mathrm{SCH}-\Delta 39-121$ but not $\mathrm{P} 0-\mathrm{SCH}-\Delta$ Cter mutant mice provides an explanation for the abnormally short internodes. Moreover, an increased number of Schwann cells was found in
P0Cre; $N f 2^{f l o x 2 / f l o x 2}$ mice. These alterations are likely to result from the impaired control of cell cycle in the absence of schwannomin (McClatchey et al., 1998; Giovannini et al., 1999, 2000). A similar mechanism has been proposed to explain the existence of short internodes in young mice deficient for PMP22, which is also implicated in cell proliferation and apoptosis (Neuberg et al., 1999). In support of this hypothesis, short internodes were not observed in $\mathrm{P} 0-\mathrm{SCH}-\Delta$ Cter mice that displayed no tendency to increased Schwann cell proliferation (Giovannini et al., 1999).

The combination of the three types of mutant mice used in the present study allows a better understanding of the function of schwannomin. Most of the findings in $\mathrm{P} 0-\mathrm{SCH}-\Delta 39-121$ and $\mathrm{P} 0-\mathrm{SCH}-\Delta$ Cter mice that overexpressed a mutated protein were qualitatively similar to those in P0Cre; $\mathrm{Nf} 2^{\text {flox2/flox2 }}$ that had a dramatic decrease in its expression levels (McClatchey et al., 1998; Giovannini et al., 1999, 2000). This indicated that the phenotype was attributable to a loss of function of the normal Nf2 gene product, because of its absence or a dominant-negative effect of overexpressed mutated protein. Moreover, it is striking that the tumorigenic (SCH- $339-121)$ and nontumorigenic (SCH$\Delta$ Cter) mutations had similar phenotypes, clearly dissociating the dual role of schwannomin in cell growth control and in cellcell interactions.

In addition, our results provide novel clues about the pathophysiology of the human familial NF2 disease, raising the possibility that peripheral nerves might be altered besides the occurrence of tumors. Our results suggest that some schwannomin mutations, even at the hemizygous stage, before the occurrence of tumors, may have a dominant-negative effect. It is also possible that a gene dosage effect occurs, especially taking into account the long lifespan of humans compared with mice. Neuropathies have been reported in NF2 patients that may not be all accounted for by microcompressions (Sperfeld et al., 2002). Our results suggest that primary alterations in Schwann cell biology may also play a role in these neuropathies and provide an incentive for further exploring this issue, which may have diagnostic and therapeutic implications.

\section{References}

Arroyo EJ, Scherer SS (2000) On the molecular architecture of myelinated fibers. Histochem Cell Biol 113:1-18.

Bhat MA, Rios JC, Lu Y, Garcia-Fresco GP, Ching W, St Martin M, Li J, Einheber S, Chesler M, Rosenbluth J, Salzer JL, Bellen HJ (2001) Axonglia interactions and the domain organization of myelinated axons requires neurexin IV/Caspr/Paranodin. Neuron 30:369-383.

Boyle ME, Berglund EO, Murai KK, Weber L, Peles E, Ranscht B (2001) Contactin orchestrates assembly of the septate-like junctions at the paranode in myelinated peripheral nerve. Neuron 30:385-397.

Chang BJ, Cho IJ, Brophy PJ (2000) A study on the immunocytochemical localization of neurofascin in rat sciatic nerve. J Vet Sci 1:67-71.

Denisenko-Nehrbass N, Goutebroze L, Galvez T, Bonnon C, Stankoff B, Ezan P, Giovannini M, Faivre-Sarrailh C, Girault JA (2003) Association of Caspr/paranodin with tumour suppressor schwannomin/merlin and betal integrin in the central nervous system. J Neurochem 84:209-221.

Dupree JL, Girault JA, Popko B (1999) Axo-glial interactions regulate the localization of axonal paranodal proteins. J Cell Biol 147:1145-1152.

Fannon AM, Sherman DL, Ilyina-Gragerova G, Brophy PJ, Friedrich VL Jr, Colman DR (1995) Novel E-cadherin-mediated adhesion in peripheral nerve: Schwann cell architecture is stabilized by autotypic adherens junctions. J Cell Biol 129:189-202.

Fernandez-Valle C, Tang Y, Ricard J, Rodenas-Ruano A, Taylor A, Hackler E, Biggerstaff J, Iacovelli J (2002) Paxillin binds schwannomin and regulates its density-dependent localization and effect on cell morphology. Nat Genet 31:354-362.

Friede RL (1983) Variance in relative internode length (1/d) in the rat and its presumed significance for the safety factor and neuropathy. J Neurol Sci 60:89-104 
Garratt AN, Voiculescu O, Topilko P, Charnay P, Birchmeier C (2000) A dual role of erbB2 in myelination and in expansion of the schwann cell precursor pool. J Cell Biol 148:1035-1046.

Gatzinsky KP, Berthold CH, Rydmark M (1991) Axon-Schwann cell networks are regular components of nodal regions in normal large nerve fibres of cat spinal roots. Neurosci Lett 124:264-268.

Giovannini M, Robanus-Maandag E, Niwa-Kawakita M, van der Valk M, Woodruff JM, Goutebroze L, Mérel P, Berns A, Thomas G (1999) Schwann cell hyperplasia and tumors in transgenic mice expressing a naturally occurring mutant NF2 protein. Genes Dev 13:978-986.

Giovannini M, Robanus-Maandag E, van der Valk M, Niwa-Kawakita M, Abramowski V, Goutebroze L, Woodruff JM, Berns A, Thomas G (2000) Conditional biallelic Nf2 mutation in the mouse promotes manifestations of human neurofibromatosis type 2. Genes Dev 14:1617-1630.

Girault JA, Peles E (2002) Development of nodes of Ranvier. Curr Opin Neurobiol 12:476-485.

Gould RM, Byrd AL, Barbarese E (1995) The number of Schmidt-Lanterman incisures is more than doubled in shiverer PNS myelin sheaths. J Neurocytol 24:85-98.

Goutebroze L, Carnaud M, Denisenko N, Boutterin MC, Girault JA (2003) Syndecan-3 and syndecan-4 are enriched in Schwann cell perinodal processes. BMC Neurosci 4:29.

Grove M, Komiyama NH, Nave KA, Grant SG, Sherman DL, Brophy PJ (2007) FAK is required for axonal sorting by Schwann cells. J Cell Biol 176:277-282.

Hoshi T, Suzuki A, Hayashi S, Tohyama K, Hayashi A, Yamaguchi Y, Takeuchi K, Baba H (2007) Nodal protrusions, increased Schmidt-Lanterman incisures, and paranodal disorganization are characteristic features of sulfatide-deficient peripheral nerves. Glia 55:584-594.

Jessen KR, Mirsky R (2005) The origin and development of glial cells in peripheral nerves. Nat Rev Neurosci 6:671-682.

Kalamarides M, Niwa-Kawakita M, Leblois H, Abramowski V, Perricaudet M, Janin A, Thomas G, Gutmann DH, Giovannini M (2002) Nf2 gene inactivation in arachnoidal cells is rate-limiting for meningioma development in the mouse. Genes Dev 16:1060-1065.

Kordeli E, Davis J, Trapp B, Bennett V (1990) An isoform of ankyrin is localized at nodes of Ranvier in myelinated axons of central and peripheral nerves. J Cell Biol 110:1341-1352.

Lallemand D, Curto M, Saotome I, Giovannini M, McClatchey AI (2003) NF2 deficiency promotes tumorigenesis and metastasis by destabilizing adherens junctions. Genes Dev 17:1090-1100.

Mathis C, Denisenko-Nehrbass N, Girault JA, Borrelli E (2001) Essential role of oligodendrocytes in the formation and maintenance of central nervous system nodal regions. Development 128:4881-4890.

McClatchey AI, Giovannini M (2005) Membrane organization and tumorigenesis-the NF2 tumor suppressor, merlin. Genes Dev 19:2265-2277.

McClatchey AI, Saotome I, Mercer K, Crowley D, Gusella JF, Bronson RT, Jacks T (1998) Mice heterozygous for a mutation at the Nf2 tumor suppressor locus develop a range of highly metastatic tumors. Genes Dev 12:1121-1133.

Melendez-Vasquez CV, Rios JC, Zanazzi G, Lambert S, Bretscher A, Salzer JL (2001) Nodes of Ranvier form in association with ezrin-radixin-moesin (ERM)- positive Schwann cell processes. Proc Natl Acad Sci U S A 98:1235-1240.

Menegoz M, Gaspar P, Le Bert M, Galvez T, Burgaya F, Palfrey C, Ezan P, Arnos F, Girault JA (1997) Paranodin, a glycoprotein of neuronal paranodal membranes. Neuron 19:319-331.

Michailov GV, Sereda MW, Brinkmann BG, Fischer TM, Haug B, Birchmeier C, Role L, Lai C, Schwab MH, Nave KA (2004) Axonal neuregulin-1 regulates myelin sheath thickness. Science 304:700-703.

Morrison H, Sperka T, Manent J, Giovannini M, Ponta H, Herrlich P (2007) Merlin/neurofibromatosis type 2 suppresses growth by inhibiting the activation of Ras and Rac. Cancer Res 67:520-527.

Neuberg DH, Sancho S, Suter U (1999) Altered molecular architecture of peripheral nerves in mice lacking the peripheral myelin protein 22 or connexin32. J Neurosci Res 58:612-623.

Obremski VJ, Hall AM, Fernandez-Valle C (1998) Merlin, the neurofibromatosis type 2 gene product, and betal integrin associate in isolated and differentiating Schwann cells. J Neurobiol 37:487-501.

Okada T, Lopez-Lago M, Giancotti FG (2005) Merlin/NF-2 mediates contact inhibition of growth by suppressing recruitment of Rac to the plasma membrane. J Cell Biol 171:361-371.
Okada T, You L, Giancotti FG (2007) Shedding light on Merlin's wizardry. Trends Cell Biol 17:222-229.

Perrin-Tricaud C, Rutishauser U, Tricaud N (2007) P120 catenin is required for thickening of Schwann cell myelin. Mol Cell Neurosci 35:120-129.

Poliak S, Peles E (2003) The local differentiation of myelinated axons at nodes of Ranvier. Nat Rev Neurosci 4:968-980.

Poliak S, Gollan L, Salomon D, Berglund EO, Ohara R, Ranscht B, Peles E (2001) Localization of Caspr2 in myelinated nerves depends on axon-glia interactions and the generation of barriers along the axon. J Neurosci 21:7568-7575.

Poulikakos PI, Xiao GH, Gallagher R, Jablonski S, Jhanwar SC, Testa JR (2006) Re-expression of the tumor suppressor NF2/merlin inhibits invasiveness in mesothelioma cells and negatively regulates FAK. Oncogene 25:5960-5968.

Rangwala R, Banine F, Borg JP, Sherman LS (2005) Erbin regulates mitogen-activated protein (MAP) kinase activation and MAP kinasedependent interactions between Merlin and adherens junction protein complexes in Schwann cells. J Biol Chem 280:11790-11797.

Robertson JD (1958) The ultrastructure of Schmidt-Lanterman clefts and related shearing defects of the myelin sheath. J Biophys Biochem Cytol 4:39-46.

Rouleau GA, Merel P, Lutchman M, Sanson M, Zucman J, Marineau C, HoangXuan K, Demczuk S, Desmaze C, Plougastel B, Pulst SM, Lenoir G, Bijlsma E, Fashold R, Dumanski J, de Jong P, Parry D, Eldridge R, Aurias A, Delattre O, Thomas G (1993) Alteration in a new gene encoding a putative membraneorganizing protein causes neuro-fibromatosis type 2. Nature 363:515-521.

Salzer JL (2003) Polarized domains of myelinated axons. Neuron 40:297-318.

Schafer DP, Bansal R, Hedstrom KL, Pfeiffer SE, Rasband MN (2004) Does paranode formation and maintenance require partitioning of neurofascin 155 into lipid rafts? J Neurosci 24:3176-3185.

Scherer SS, Gutmann DH (1996) Expression of the neurofibromatosis 2 tumor suppressor gene product, merlin, in Schwann cells. J Neurosci Res 46:595-605.

Sharghi-Namini S, Turmaine M, Meier C, Sahni V, Umehara F, Jessen KR, Mirsky R (2006) The structural and functional integrity of peripheral nerves depends on the glial-derived signal desert hedgehog. J Neurosci 26:6364-6376.

Shaw RJ, Paez JG, Curto M, Yaktine A, Pruitt WM, Saotome I, O’Bryan JP, Gupta V, Ratner N, Der CJ, Jacks T, McClatchey AI (2001) The Nf2 tumor suppressor, merlin, functions in Rac-dependent signaling. Dev Cell 1:63-72.

Sherman DL, Brophy PJ (2005) Mechanisms of axon ensheathment and myelin growth. Nat Rev Neurosci 6:683-690.

Sperfeld AD, Hein C, Schröder JM, Ludolph AC, Hanemann CO (2002) Occurrence and characterization of peripheral nerve involvement in neurofibromatosis type 2. Brain 125:996-1004.

Stickney JT, Bacon WC, Rojas M, Ratner N, Ip W (2004) Activation of the tumor suppressor merlin modulates its interaction with lipid rafts. Cancer Res 64:2717-2724.

Tait S, Gunn-Moore F, Collinson JM, Huang J, Lubetzki C, Pedraza L, Sherman DL, Colman DR, Brophy PJ (2000) An oligodendrocyte cell adhesion molecule at the site of assembly of the paranodal axo-glial junction. J Cell Biol 150:657-666.

Taylor AR, Geden SE, Fernandez-Valle C (2003) Formation of a betal integrin signaling complex in Schwann cells is independent of rho. Glia 41:94-104.

Tricaud N, Perrin-Tricaud C, Brusés JL, Rutishauser U (2005) Adherens junctions in myelinating Schwann cells stabilize Schmidt-Lanterman incisures via recruitment of p120 catenin to E-cadherin. J Neurosci 25:3259-3269.

Trofatter JA, MacCollin MM, Rutter JL, Murrell JR, Duyao MP, Parry DM, Eldridge R, Kley N, Menon AG, Pulaski K, Haase VH, Ambrose CM, Munroe D, Bove C, Haines JL, Martuza RL, MacDonald ME, Seizenger BR, Short MP, Buckler AJ, Gusella JF (1993) A novel moesin-, ezrin-, radixin-like gene is a candidate for the neurofibromatosis 2 tumor suppressor. Cell 72:791-800.

Wang H, Kunkel DD, Martin TM, Schwartzkroin PA, Tempel BL (1993) Heteromultimeric $\mathrm{K}^{+}$channels in terminal and juxtaparanodal regions of neurons. Nature 365:75-79.

Zhang SM, Marsh R, Ratner N, Brackenbury R (1995) Myelin glycoprotein P0 is expressed at early stages of chicken and rat embryogenesis. J Neurosci Res 40:241-250. 